\title{
Gorham's disease that gave response to radiotherapy
}

\author{
Sule Karabulut Gul ${ }^{1,}$, Ahmet Fatih Oruc ${ }^{1}$, Duygu Gedik ${ }^{1}$, Hakan Levent Gul ${ }^{2}$, Atınc Aksu ${ }^{1}$, \\ Alpaslan Mayadagli ${ }^{3}$
}

${ }^{1}$ Kartal Education and Research Hospital, Department of Radiation Oncology, Istanbul, TR

${ }^{2}$ Fatih Uninersity, Medical Faculty, Department of Neurology, Istanbul, TR

${ }^{3}$ Bezmi Alem University, Medical Faculty, Department of Radiation Oncology, Istanbul, TR

\section{Email address:}

sulegul2003@yahoo.com (S. K. Gul)

\section{To cite this article:}

Sule Karabulut Gul, Ahmet Fatih Oruc, Duygu Gedik, Hakan Levent Gul, Atınc Aksu, Alpaslan Mayadagli. Gorham's Disease that Gave Response to Radiotherapy. Journal of Cancer Treatment and Research. Vol. 2, No. 5, 2014, pp. 45-47. doi: 10.11648/j.jctr.20140205.11

\begin{abstract}
Background: Gorham's disease is a disorder that results as destruction and resorption of osseous matrix and is characterized by proliferation of vascular channels. We here reported a rare case of Gorham's disease that gave response to radiotherapy. Our aim is to remind the clinicians about this rare entity, and to discuss the etiopathology, clinical presentation and treatment options for patients with Gorham's disease. Case Report: 32 years old male patient had admitted to neurosurgery department for pain, weakness and limitation of motion at the head and neck. Osteolysis was detected at the bodies of 1, 2 and 3. vertebrae. After a number of examinations and excisional biopsy, the patient was diagnosed as Gorham's disease. Cervical stabilization was made but after 3 years, the patient's complaints had occurred again and a restabilization was made. 2 years after; with increased complaints, the patient was send to our clinic for consultation and radiotherapy (RT) was applied to the destructive parts of the bones. 2 months after RT, the patients' complaints had a significant decrease both clinically and radiologically. Conclusion: Gorham's disease can be seen in both men, women and at any age group, although most cases are diagnosed before the age of 40 years. No familial predisposition has been found. The disease may affect the appendicular or the axial skeleton. The exact nature of the disease process is unknown. The medical treatment for Gorham's disease includes radiation therapy, anti-osteoclastic medications (bisphosphonates), and alpha-2b interferon. As laboratory studies are usually within normal limits in most cases, diagnosis can often be delayed. By the light of clinical findings with characteristic radiographic and histopathological findings, an early diagnosis can be possible.
\end{abstract}

Keywords: Bone Disease, Neurosurgery, Osteolysis, Radiotherapy

\section{Introduction}

Gorham's disease is an extremely rare disorder of the musculoskeletal system. In 1954, Gorham and colleagues reported on two patients with massive osteolysis of the bone (1). In 1955, Gorham and Stout provided a more comprehensive report on this subject (2). Based on their experience and the available case reports from the literature, they found that "Gorham's disease is usually associated with an angiomatosis of blood vessels and sometimes of lymphatic vessels, which seemingly are responsible for it".

In the past 59 years, numerous papers have been published about Gorham's disease but the etiology of Gorham's disease still remains poorly understood and largely unknown (3).

\section{Case Report}

32 years old male patient had complaints of pain, weakness and limitation of motion at his neck and head. He had admitted to the department of neurosurgery, and his cervical computed tomography scans (CT) showed osteolysis and destruction at the bone bodies of 1.,2. and 3. vertebrae. The whole bone structure was scanned but no additional lesion was detected. Excisional biopsy showed diffuse hemangiomatosis at the spongious bone tissue and significantly increased osteoclastic activity around the cortical tissue with bone resorption.

With diagnose of Gorham's disease, cervical stabilization was applied to the patient. After 3 years, he had admitted to hospital with severe head and neck pain and fracture was detected at the same area. Restabilization was applied and Clodronate $(1600 \mathrm{mg} /$ day) therapy was started for 2 years. 
As the severity of pain(Visual Analog Scale(VAS):9) and lytic lesions had increased in his follow up, the patient was send to our clinic for consultation and radiotherapy(RT) was applied to the destructive parts of the bones at 18 fractions with a dose of 36 Gy. 2 months after RT, the patients complaints had a significant decrease (VAS:1) both clinically and radiologically(Figure-1: osteolysis before radiotherapry. Figure-2: osteolysis after radiotherapy).

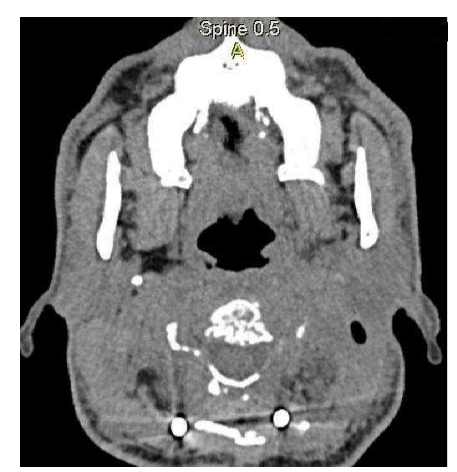

Figure 1. osteolysis before radiotherapry

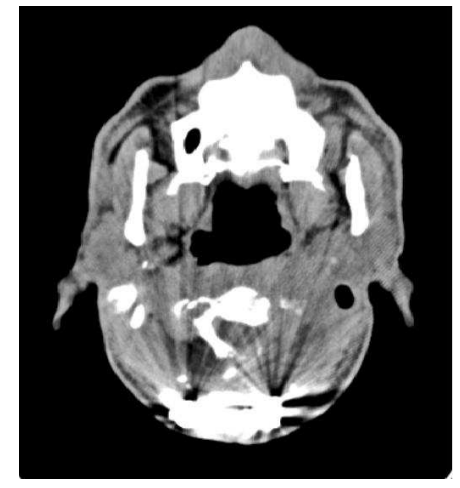

Figure 2. osteolysis after radiotherapy

\section{Conclusion}

The etiology and pathophysiology of this poorly understood disease have not been determined yet. The pathological process is the replacement of normal bone by an aggressively expanding but non-neoplastic vascular tissue, similar to a hemangioma or lymphangioma(4-7). Proliferating neovascular tissue causes massive bone loss. At the early stage of the lesion, the bone undergoes resorption, and is replaced by hypervascular fibrous connective tissue and angiomatous tissue. Involved bones histologically show a non-malignant proliferation of thin-walled vessels; the proliferative vessels may be capillary, sinusoidal or cavernous. At the late stages, there is progressive dissolution of the bone leading to massive osteolysis, with the osseous tissue being replaced by fibrous tissue. The stimulus that generates this change in the bone is unknown (5).

Clinical manifestations can vary and depend on the affected site. Presentations can be as a relatively abrupt onset of pain and swelling in the affected extremity, or with history of insidious onset of pain, limitation of motion, and progressive weakness in the involved limb. This may be accompanied with soft-tissue weakness and/or atrophy. History of significant trauma makes the limb painful, forcing the patients to report their symptoms to their family physician and providing for an early diagnosis of Gorham's disease in some cases.

The degree of osseous deformity in patients with Gorham's disease may become severe, but serious complications are not frequent. Paraplegia related to spinal cord involvement may occur in patients who have involvement of vertebrae with resultant osteolysis(8). Thoracic cage, pulmonary, or pleural involvement can lead to compromise of respiratory function and death can ensue. Infections of bone and septic shock have also been rarely reported.

Some imaging methods can be used in the evaluation of Gorham's disease. Plain radiographs, radioisotope bone scans, computed tomography (CT), and magnetic resonance imaging (MRI) have all been used in such evaluations (7,911).

Clinicians have to rule out other common (in contrast to the extremely rare Gorham's disease) underlying causes of osteolysis such as infection, cancer (primary or metastatic), inflammatory or endocrine disorders for diagnose.

So that the disease is rare, there is no standard therapy available. The medical treatment for Gorham's disease includes radiation therapy, anti-osteoclastic medication (bisphosphonates), and alpha-2b interferon (12-15). The principal treatment modalities are surgery and radiation therapy. Surgical methods are: resection of the lesion, and reconstruction using bone grafts and/or prostheses. Definitive radiation therapy in moderate doses (40-45 Gy in 2 Gy fractions) appears to result in a good clinical outcome with few long-term complications (16). If vital structures are not involved, the prognosis for patients with Gorham's disease is generally good.

Physicians must take a detailed history and perform a complete physical examination for all patients who present with osteolysis of the shoulder or pelvic girdle, long bones, or vertebrae. When diagnosed: definitive radiation therapy in moderate doses can give good response to clinical outcome with few long-term complications.

\section{References}

[1] Gorham LW, Wright AW, Shultz HH, Maxon FC, Jr. Disappearing bones: a rare form of massive osteolysis: report of two cases, one with autopsy findings. Am J Med 1954;17:674-682.

[2] Gorham LW, Stout AP. Massive osteolysis (acute spontaneous absorption of bone, phantom bone, disappearing bone): its relation to hemangiomatosis. $\mathrm{J}$ Bone Joint Surg [Am] 1955;37-A:985-1004.

[3] Patel DV. Gorham's disease or massive osteolysis. Clin Med Res. 2005 May;3(2):65-74.

[4] Dickson GR, Hamilton A, Hayes D, Carr KE, Davis R, Mollan RA. An investigation of vanishing bone disease. Bone 1990;11:205-210. 
[5] Devlin RD, Bone HG 3rd, Roodman GD. Interleukin-6: a potential mediator of the massive osteolysis in patients with Gorham-Stout disease. J Clin Endocrinol Metab 1996;81:1893-1897.

[6] Pazzaglia UE, Andrini L, Bonato M, Leutner M. Pathology of disappearing bone disease: a case report with immunohistochemical study. Int Orthop 1997;21:303-307.

[7] Spieth ME, Greenspan A, Forrester DM, Ansari AN, Kimura RL, Gleason-Jordan I. Gorham's disease of the radius: radiographic, scintigraphic, and MRI findings with pathologic correlation. A case report and review of the literature. Skeletal Radiol 1997;26:659-663.

[8] Halliday DR, Dahlin DC, Pugh DG, Young HH. Massive osteolysis and angiomatosis. Radiology 1964;82:637-644.

[9] Ceroni D, De Coulon G, Regusci M, Kaelin A. Gorham-Stout disease of costo-vertebral localization: radiographic, scintigraphic, computed tomography, and magnetic resonance imaging findings. Acta Radiol 2004;45:464-468.

[10] Assoun J, Richardi G, Railhac JJ, Le Guennec P, Caulier M, Dromer C, Sixou L, Fournie B, Mansat M, Durroux D. CT and MRI of massive osteolysis of Gorham. J Comput Assist Tomogr 1994;18:981-984.
[11] Dominguez R, Washowich TL. Gorham's disease or vanishing bone disease: plain film, CT, and MRI findings of two cases. Pediatr Radiol 1994;24:316-318.

[12] Hagberg H, Lamberg K, Astrom G. Alpha-2b interferon and oral clodronate for Gorham's disease. Lancet 1997;350(9094):1822-1823.

[13] Fontanesi J. Radiation therapy in the treatment of Gorham disease. J Pediatr Hematol Oncol 2003;25:816-817.

[14] Lee S, Finn L, Sze RW, Perkins JA, Sie KC. Gorham Stout syndrome (disappearing bone disease): two additional case reports and a review of the literature. Arch Otolaryngol Head Neck Surg 2003;129:1340-1343.

[15] Handl-Zeller L, Hohenberg G. Radiotherapy of Morbus Gorham-Stout: the biological value of low irradiation dose. $\mathrm{Br}$ J Radiol 1990;63(747):206-208.

[16] Dunbar SF, Rosenberg A, Mankin H, Rosenthal D, Suit HD. Gorham's massive osteolysis: the role of radiation therapy and a review of the literature. Int $\mathbf{J}$ Radiat Oncol Biol Phys 1993;26:491-497. 